\title{
Occupation diversification strategy of Delas Village of Southern Bangka in a post-tin mining era
}

\section{Strategi diversifikasi mata pencaharian masyarakat Desa Delas pasca penambang timah Air Gegas, Bangka Selatan}

\author{
Herdiyanti \\ Department of Sociology, Faculty of Social and Political Sciences, Universitas Bangka Belitung \\ Address: Kampus Terpadu Balunijuk, Merawang, Bangka, Bangka Belitung 33172 \\ E-mail: vhie_dyan@yahoo.co.id
}

\begin{abstract}
This research refers to the social-economic situation of Bangka people, in particular, a community in Delas Village in the Air Gegas district of Southern Bangka. The aim of this research is to explain the survival strategies adopted by Delas people in the post-tin mining era. This research applies descriptive qualitative research. Findings in the field show that a factor that influences survivability in the post-mining era is the creativity of the Delas people. To provide a livelihood in the post-mining era, individuals are encouraged to be more active and creative to more wisely manage natural resources. People also possess various assets in natural and physical capital, financial capital, human, and social capital. Based on research, creative process conducted by make diversification of occupation from natural resource. Occupational diversification is a new post-mining era survival strategy of the Delas people. This research shows that various activities are performed as part of this strategy, such as utilizing former mining land for freshwater fish farming or rearing livestock, which in turn minimizes mining activities.
\end{abstract}

Keywords: livelihood strategies; diversification; post-tin; social capital

\begin{abstract}
Abstrak
Penelitian ini merupakan salah satu penelitian yang merujuk pada kondisi social ekonomi masyarakat Bangka khusunya masyarakat Desa Delas, Kecamatan Air Gegas, Kabupaten Bangka Selatan. Tujuan dari penelitian ini untuk menjelaskan strategi bertahan hidup yang diterapkan oleh masyarakat Desa Delas pasca panambang timah. Penelitian ini menggunakan metode penelitian kualitatif deskriptif. Hasil temuan di lapangan menunjukkan bahwa kreatifitas masyarakat menjadi faktor pendukung dan pendorong dari proses bertahan hidup masyarakat Desa Delas pasca penambang timah. Kondisi pasca penambang timah mendorong masyarakat untuk lebih aktif dan kreatif dalam mengelola alam secara bijak dan arif dalam melangsungkan kehidupan. Beragam aset yang dimiliki oleh masyarakat mulai dari modal alam, fisik, finansial, social dan manusia. Berdasarkan hasil penelitian, proses kreatifitas yang dilakukan oleh masyarakat diantaranya melakukan diversifikasi perkerjaan dari ragam potensi alam yang dimilikinya. Diversifikasi pekerjaan merupakan salah satu strategi bertahan hidup masyarakat pasca penambang timah yang diakukan oleh masyarakat Desa Delas. Simpulan dari hasil penelitian ini menunjukkan beberapa aktivitas diversifikasi yang dilakukan oleh masyarakat diantaranya memanfaatkan bekas lahan tambang sebagai budidaya ikan air tawar dan beternak, hal ini bertujuan untuk meminimalisir aktivitas tambang.
\end{abstract}

Kata kunci: strategi penghidupan; diversifikasi; pasca timah; modal sosial

\section{Introduction}

Bangka Belitung is a province with remarkable natural potential to improve people welfare in various aspects. The abundant natural resources can be developed to suit the needs of the local community. Bangka Belitung also known as the largest tin producer in Indonesia. The majority of rural people rely their source of income from mining, agriculture and plantation sectors. However, different conditions occurs in Delas Village, which become the locus of this research. Tin start to generate threat for people livelihood and also become increasingly rare, thus, Delas Village people should be able to develop other sources of livelihood other than mining sector.

As basic needs to live are increasing, people are required to be more creative in expanding sources of income to fulfil their daily needs. Such condition can be influenced by internal and external factors, 
or the combination of both. According to Supriyadi (2007:20), livelihoods are the main source of work carried out by individuals to fulfil daily need in life by utilizing any kind of resources available in their environment. Changes in livelihood activities are regarded as changes experienced by the community in determining and influencing subsequent socio-economic actions. In general, social change is a process to shift or to alter social structures in the community.

Livelihood strategies of rural communities was highly rely on natural resources available in their environment. According to Sajogyo (in Dharmawan 2007), livelihoods in rural communities are divided into two sectors, agricultural and non-agricultural sectors. Whereas, according to Ramli (2007) livelihood system is characterized by the division of agricultural and non-agricultural system. Scoones (1998) argued that there are various kinds of livelihood strategies in each household which implemented through a series of activities in obtaining additional income. In addition, each household is required to use and select the right assets and preserve them to maintain their livelihood. The community was also required to utilize the available resources to sustain post-tin era. In post-tin era, livelihood is a survival strategy carried out by the community after a drastic changes or pressures by utilizing resources owned by the community. Resources is defined as assets or wealth possessed by village communities. The option of available resources in the environment lead village community to determine more dominant resources used as anticipation strategies. Opening and redeveloping the agricultural and plantation sectors and eliminate dependency on mining sector has become one of the main strategy applied by Delas Village people. The agriculture and plantation sectors are natural resources owned by the Delas Village community, thus become the main assets in performing livelihood strategy.

Social capital is generally perceived as concept which has been widely studied by experts in social studies. In this research, social capital is used as a basic indicator in analyzing development process that focuses on community group performance. Syahra (2003) defined social capital as an essential real assets for people's lives, arranged through cooperation from social relations which further formed a social group. In other words, there is a social relationship built within the formation of social group. According to Woolcock (2001) social capital consists of norms and networks that facilitate collective action to achieve same goals in community. The definition of social capital proposed by Woolcock is capital that arises from common fate and norms through the formation of collective action. Collective action fueled by mutual trust in and social interaction within the community. Social interactions will create social relations in the community. According to Hasbulah (2006) social capital plays important role in functioning and strengthening community survivability. Social capital is perceived as an essential component create a sense of belonging, mobility of idea, mutual trust and sense of mutual benefit and cooperation. Such relationship identified as a form of social capital built by the community. Thus, social capital has become a theoretical reference and the concept used by researcher in analyzing the subject. Therefore, it becomes important to describe how community livelihood strategies in post tin mining era in Delas Village.

Related to this study, researcher refer to several previous studies as literature review. The previous research, including research from Herdiyanti (2017) analysed the Identification of Community Social Capital to Post-Mining Land Restoration, explained that post-mining conditions encourage people to take survival actions in post-tin life. This study discusses the role of social capital in dealing with post-tin conditions which directed through a land restoration program managed by the Central Bangka Regency Government and the Ministry of Environment. This program aims to minimize environmental damage due to mining activities. Existing mining land conditions have encouraged the Central Bangka Regency Government to take the initiative to carry out the restoration program, which has been implemented for over than a year and inviting various stakeholders to help run the program. However, program implementation will not achieved the desired means without the intervention of district government and the Ministry of Environment. Yet, community involvement is needed in post-mining land restoration program activities. Both intervention and involvement is an element of social capital which develop social capital elements in the future.

Research conducted by Martopo (2012) on Sustainable Livelihood Studies examined two villages in Kejajar Subdistrict, Wonosobo Regency. Findings from the field displays that there are substantial 
problems regarding land damage in the area, identified as moderate and heavy damage ranging from the scope of broad to narrow, namely Buntu Village and Tambi. This research shows the results of livelihood assets in this village such as human capital, natural capital, social and physical as well as financial are categorized as unsustainable livelihood assets or do not have potential benefits for the Buntu Village community. But different conditions occur in Tambi Village related to their livelihood assets. Livelihood assets such as human capital are categorized as unsustainable assets, while natural and physical capital are categorized as sustainable assets. Meanwhile, social and financial capital are categorized as unsustainable one.

Research conducted by Belda \& Christanto (2012) on Fishermen's Livelihood Strategies in Increasing Community Economy in Sasak Ranah Pesisir and Sungai Beremas Subdistricts, focusing their studies on Sasak Ranah Pasisie and Sungai Beremas Districts. The research aims to draw the relations between assets, access, and activities with the economic situation of the coastal communities of Sasak Ranah Pesisir and Sungai Beremas Subdistricts. Researcher also find the reason underlies poor economic situation of coastal fishing communities in Sasak Ranah Pesisir and Sungai Beremas Subdistricts, given the large potential of the area. This research also describes the knowledge of fishermen of coastal livelihood strategies in utilizing natural resources optimally to improve the economy of the Sasak Ranah Pasisie and Sungai Beremas sub-districts. The results of the study shows that the conditions of assets in the research area as follows: the causes of low economic, fishing community strategies in sustaining life. In general, assets of Sasak Ranah Pasisie and Sungai Beremas Districts can be sustained if the assets are utilized optimally.

This research employs concept of social capital in analyzing focus of the research. Social capital is a concept to bridge concept from sociology and economy. The concept grew from theoretical buildings from relatively new research, even though social capital concept has been employed in various field of discipline. Baiquni (2007) explained that within social concept there are urge to take action in live through network and relations built upon beneficial trust and cooperation.

According to Woolcock (1998), social capital is one of the most important assets in live consists of norms and network. Capital and networks provide convenience for collective measure to achieve common goals. Social capital grows its substance in social interaction processes performed by community in forming social relations. Confidence, network, and norms are basic concepts in social capital, produced by consensus in community. Woolcock (2006:83) argues that social capital could not be perceived as a single entity. Rather, it should be regarded as multidimensional concept with characteristics such as bonding, bridging, and linking. Achieving common goal requires important role of actors such as cooperation to survive. Social capital are likely strengthen exclusive identities and homogeneous groups. Bonding social capital is a reciprocal relationship that could increase the sense of solidarity among individuals. Social capital bonding can create group loyalty and lead to a strong possibility of conflict with the outside group. Social capital bonding is the base of society because of equality and common goals formed in a group. Thus, social capital bonding has become an essential capital to resolve problems occurred in society by its interaction.

Social capital bridging produce identities and reciprocal relations which could increase trust among related parties, while social capital bonding draws more limited relations compare to social capital bridging. The ability of social capital bridging to provide and spread information become the main advantage of community in terms of accessibility. In addition, social capital bridging could support the creation of beneficial relations development. The process to achieve common goals was based on interest and needs. The interaction process conducted by various stakeholders, particularly with external parties, are mainly beneficial. The next concept is social capital linking, defined as a relations occurred outside the prevailing environment and community with different condition which give more access to more dominant individual to use resource outside the community. Social capital linking formed within society, utilized as a reliable source for various interest. Individual will gain benefit based on participation within the group and social construction that was intentionally built to create resources. Network was not only limited to horizontal relations, but also vertical structure. 
The network is important to provide dynamics in problem solving method. The great trust level and norms is the substance of social capital applied in social relations (capital bonding, capital bridging, and social capital linking), which was initiated by Michael Woolcock is expected to facilitate behaviour to achieve common goals. Therefore, this research aims to analyze strategy of occupation as livelihood in Post-tin society in Delas village.

Woolcock (2001: 13) mentioned four social network models which consist of two bottom up social network models and two top downs type. The bottom ups consists of integration and linkage. Integration formed in the community, while networking take base on the availability of resources outside the community. Top down social networks consist of integrity (synergy). Integrity is the level of efficiency and effectiveness in the group while synergy created in external network. Based on the four social network models proposed by Woolcock, social networks plays more active role in the Delas Village community. The dynamics in the situation preceded by social capital bonding bonds with social capital bridging within a harmonious relationship. There is a binding relation from internal scope (bottom up) to the external space (top down) in forming a synergistic relationship with the community. This study will illustrate the role of the relationship in shifting livelihood activities of Delas Village people. In addition, the framework applied illustrates how the relations encourage selection and utilization process of livelihood assets available to the Delas Village community environment.

\section{Research Method}

This research is a qualitative study that applied case study approach. Observation, in-depth interviews and documentation applied as data collection methods. According to Rahman \& Ibrahim (2009) the data analysis technique used is descriptive qualitative study on diversification of people's livelihoods in Delas Village in post-tin mining era. Researcher also employ direct observations in Delas Village to obtain general picture of the village including village demographics, sources of livelihood and character of the population, and interactions of Delas Village people. Creswell (2007:73) stated that qualitative research approach can explore a phenomenon or case in detail has been determined through in-depth data collection that involves information on several sources (for example, observation, indepth interviews, and documents and reports).

The next step refers to Cresswell (2010) in supporting researcher during filed observation. Researcher collected the concept that has been compiled before field observation. The concept will be negotiated based on findings in the field. Data collection process gathered through experiments, observations / observations, historical and in-depth interview techniques, conducting Focused Group Discussions (FGD) on stakeholders, including village heads, fertilizer warehouse owners, community leaders, and originators and "Mentari Pagi" fish farm owners. The number of targeted informants for the purpose of this study were 30 informants. The data analysis technique proposed descriptively based on the findings of the field. Descriptive analysis technique is applied to produce a picture of the data that has been collected based on interview.

\section{Result and Discussion}

\section{Community livelihood strategies the in post-mining era}

Communities performed various livelihood strategies in order to address priority issues in their current circumstances. Indeed, the current socio-economic system is different from the previous economic level that highly relies in mining sectors. In the post-tin mining era (2010), community livelihood activities has shifted. The dominant occupation of Delas village community relies on agricultural and plantation sectors which currently is being continuously developed. The program has been initiated since the community was no longer dependent on mining sector at the end of 2010 . In the beginning of 2011 the agriculture and plantation sectors developed. Even though income from agricultural sector was relatively lower than the mining sectors, community was enthusiastic in developing agricultural and plantation sectors. Table 1, 2, and 3 shows occupation shift of Delas People. 
Table 1.

Occupation in the period of 1980-1990's

\begin{tabular}{lc}
\hline \multicolumn{1}{c}{ Occupation } & Amount/household \\
\hline Farming & 213 \\
Gardening & 247 \\
Cattle raising & 44 \\
\hline Source: Delas village period on 2010-2016
\end{tabular}

Table 2.

Occupation in the period of 1990-2010's

\begin{tabular}{lc}
\hline \multicolumn{1}{c}{ Occupation } & Amount/household \\
\hline Farming & 23 \\
Gardening & 12 \\
Cattle raising & 16 \\
Civil servant & 12 \\
Mining & 461 \\
\hline \multicolumn{2}{c}{ Source: Delas village period of 2010-2016 }
\end{tabular}

Table 3.

Occupation in the period of 2010's-current

\begin{tabular}{lc}
\hline \multicolumn{1}{c}{ Occupation } & Amount/household \\
\hline Farming & 175 \\
Gardening & 539 \\
Cattle raising & 25 \\
Civil servant & 38 \\
Fish farming & 36 \\
Mining & - \\
\hline Source: Delas village period of $2010-2016$
\end{tabular}

Tables 1, 2, and 3 show changes in livelihood activities in Delas Village. Communities were able to make changes by developing their natural potential and assets. The availability of livelihood assets and the development of knowledge and skills in the community lead people to be more creative in finding alternative livelihoods other than the agricultural and plantation sectors.

Residents who was previously involved on mining activities, now uses ex-mining land as an alternative source, one of them is a fish pond business. Such activities are part of economic activities obtained from various livelihood strategies. Economic activity, in this term, is perceived as activities carried by humans to fulfill their needs. To meet their needs, humans seek livelihoods according to their abilities and the geographical conditions of their surroundings. Agricultural activities, in general, not only include farming, but also include plantation activities. The same situation applied in Delas Village whereas farming and gardening are carried out by the community today.

The process of livelihood becomes socially and culturally developed. Residents choose the right actions for development of agricultural and plantation sectors. The use of seeds and fertilizers was chosen selectively based on the understanding and knowledge obtained by the residents through regular weekly discussions in each neighborhood association and socialization from the Agriculture and Plantation Service. This activities generate impact on the process of community livelihood activities in the sustainability of community livelihoods, especially regarding posttin community livelihood systems. Tracing from the historical system and livelihood activities, the agricultural and farming activities are still completed through traditional measure. However, along with the development of science and technology, people become more open to a change, especially for village development sector. The current process of livelihood activities has an impact on community livelihood strategies, especially regarding the socio-economic system 
of the post-tin community. Such conditions make Delas Village a Self-sufficient Village. Not only because the community is already advanced, but also community has become familiar with mechanization and sophisticated technology and community participation in village development.

Social change is an unavoidable circumstances in human life. Every society will experience changes in comparison to society lives in the previous era. The circumstances occurred in Delas Village is one form of social change related to its livelihood system in post-tin mining era. Transformation in post-tin era could lead to positive impact on the systems compare to conditions during tin mining era. It can be regarded as a form of resilience in supporting recovery and improvement of the conditions of the posttin era. Efforts to maintain these conditions are supported by various assets available in the community. Various available potential has been utilized in the most optimum way. The five available resources including natural capital, physical capital, financial capital, human capital and available social capital. The strength of resources or assets owned by the community is not homogeneous. Therefore the activities of each community are different according to results of different achievements and livelihoods.

Rural economic activities are not solely based on the agricultural sector. Various activities and businesses can make positive contribution to the economic if it was develop sustainably. The variety of economic activities act as the main factors in livelihoods diversification. Diversification of livelihood is a form of life carried out by the community through various strategies (Ellis 1999) in Chapman \& Tripp 2006: 1). It is important to differentiate livelihoods in people's lives to improve social life towards a transformation. Similarly, according to Niehof (2004) livelihood diversification is not only aimed to fulfill life needs, but also to develop life for a betterment. Livelihood diversification is an option made by Delas Village community. The reason for choosing diversification of livelihood as a source of additional income. Thus, it does not only depend on the agricultural and plantation sectors. Meanwhile, according to Scoones (1998) livelihood diversification is carried out on the grounds as income payments.

Various reasons has become the underlying factor of livelihood diversification in fulfilling social and economic needs. The agricultural and plantation sectors are considered very important for the survival of livelihoods by the people of Delas Village. However, people outside the agricultural and plantation sectors also open alternative businesses as additional income to increase economic stability. One of the livelihood diversifications carried out by residents is fish pond business, managed individually and in groups. Alternative efforts undertaken are one form of public openness in dealing with post-tin mining livelihood strategies to gain additional income. However, livelihood diversification does not only occur in rural communities as the urban communities also performed similar strategies to sustain life.

The conditions in Delas village portrayed the initial hypothesis in this research regarding the role of social capital towards the sustainability of post-tin mining community livelihoods and the impact of changes in livelihood activities. The community also understand that cooperation and social relations will create a wider network for current economic system sustainability in developing the agricultural and plantation sectors as well as alternative businesses that has been evolved. The network is built not only with the internal stakeholders of the Delas Village community, but also reaches expanded network through stakeholders outside the village community, such as external broker and capital owner. Such situation was effectively managed due to the role of social capital works within the current economic activities.

Analysis of the role of social capital found in the Delas Village community are proceeding in an ongoing manner regardless friction occurred between residents and farmer groups. However, friction was still manageable through discussion mediated by community leaders. As explained by Woolcock, there are three types of social relations in community, namely Bonding, Bridging and Linking. Researcher found several social relations that grew in the Delas Village community environment. And provide substantial support for people in facing post-tin mining era. First, there are social capital bonds that work and grow within the community. This was demonstrated through the interaction process and high level of community participation in social relations between citizens. The process creates a sense of mutual trust, solidarity, proactive attitude and norms that bind each citizen and farmer group in implementing survival strategies. 
The practice of local wisdom of the community began to re-appear due to prevailing values and norms adopted by Delas Village community. For example, people pratice Besao, known as local wisdom and cultural value that has long been embedded in people's daily lives. Even though the cultural value has faded, the interpretation of Besao is currently re-emerging in daily activities Delas Village people. Besao is known as interaction and communication activity that conducted through cooperation between citizens to achieve mutual benefit in their social lives. In this sense, there is a reciprocal relationship that takes place in people daily interaction. Mutual relations are formed by cooperation and common interests in achieving goals related to post-tin mining era. Besao has become a main example of how local wisdom re-emerge as survival strategy for the community as people start to leave mining sectors and shift to farming and gardening. Various creative ideas has been evolving in Delas Village, one of them is how to develop possibility of livelihood activities other than the agricultural and plantation sectors. The community has succeeded in developing fish farm livelihood activities and currently being used as alternative businesses. This creation makes Delas Village classified as a proactive community towards economic growth in sustainable livelihoods. The proactive attitude grows and developed by the community, one example is the emergence of creativity and ideas in anticipating post-tin mining era strategies by developing alternative business.

This mindset makes public become more open to socio-economic progress, especially in the agricultural and plantation sectors. Majority of communities used to work as gardeners and farmers. This attitude was built because of sense of belonging and togetherness, same circumstances and common goals related to the sustainability of livelihood. Thus, work ethic emerged in building cooperation to create other possible occupation sector. This collaboration was built through several indicators such as willingness and openness to be involved in common interest-related aspects of the Delas Village Community. One method to realize the goal is through conducting weekly discussions with the intention is to obtain the right information about farming. For example is discussing strategy to select and utilize high quality seeds and fertilizers. This condition could be identified as social capital emerged in type of social bonding.

The next concept proposed in this analysis is about social capital bridging. It is evident that in industrialization era, the community survived and evolved by establishing relations with external parties such as capital owners and middlemen who have positive impact on the post-tin strategy. Social bridging is shown by relationship exists between the community and the owners of capital and middlemen from outside Delas Village. Social relations built between the two parties are based on mutually beneficial relations and still survive because it serves interest of both parties. This type of relations can be seen through the mechanism of agreement for trade, for example is to get access to pepper sales to Singapore. The agreement on stamp duty is mutually beneficial whether for public and capital owners. Community is very helpful regarding the continuity of their livelihood, because pepper is sold to the owners of capital at high prices, unlike direct sales to the city market. In the market, the price is much lower than price offered by capital owner, since capital owner are directly involved within the trade process. In one hand, capital owner will gain benefit for pepper trade direct form the farmers. The benefit also gained by cooperation built with Singapore. Broker also received income from collection and distribution process of farming product.

Delas Village is known to be very open for cooperation and relations. The relationships are heterogeneous involving parties from different backgrounds with a lot of ideas exchanges. People build networks or connections from various external parties based on the principle of equal destiny and goals for post-tin sustainability. The existing farming community provides direction on how to use the resources in surrounding environment. The information exchange starts from theory to practice about the use of sophisticated technology in developing the agricultural sector and development.

The existing social capital in Delas Village community has intersection between the dimensions of internal (bonding) and external (bridging) that connect the community in implementing livelihood strategy in post-tin mining era. The social capital formed in the community is modern social capital supported by high trust that grows sustainably within and outside the community. The trust built 
by the community is expected to create a wider network both within and outside the Delas Village community. Bonding is classified as bottom up social network and will optimally work with synergy with the top down social networks (bridging and linking). In reality, top down and bottom up mechanism work in synergy within the relations built by the community and external parties. The existing relationship lead to a great pepper harvest of Delas Village people and have reached international market to Singapore.

As explained by Woolcock (1998), a modern organization should have the element of strong embeddedness and autonomy. Modern organization has particular characters and high level of integration as it is supported by integrity among its member. This situation portrays social institution with a pattern of organized relations supported by values and norms that govern the needs of the people of Delas Village. Apart from the concept, reality of Delas Village can create a variety of social networks outside and within the Delas Village community. Referring to Woolcock's understanding of developing interrelated horizontal and vertical division with top down and bottom up relations to measure social and economic scale of people's lives (Woolcock, 2001:13). The social relations formed are based on common interests and goals between bottom up and top down mechanism which properly functioned in Delas Village community. Based on data, researcher found that top down social networks (bridging and social capital linking) interact with bottom-up social networks (social capital bonding) have produced maximum relations. The existing social capital is supported by the reality of Dellas Village community which proceed in the society and produce community integration by social groups that work synergistically with the government.

Relationship built in Delas Village become a manifestation of the community's socio-cultural system that was formed long ago, but it had changed into individualist interaction type since the mining sector was developed. However, in the post-tin mining era, socio-cultural system in community was started to develop and preserved by the community to achieve common interest in agricultural and plantation sectors development. The agriculture and plantation sector was re-developed in posttin era with the aim to achieve a better socio-economic livelihood system. Nevertheless, it cannot be avoided if the social relations goes uncontrolled and the commitment of each party cannot be maintained. There is a possibility of a conflict which can shrink the value of social capital which has been jointly built by the community and external parties. In the context, each party involved in interaction has different interests. Without social control, interests could lead to a conflict between the two parties. In essence, social capital is not always occurred in positive way. There is always a possibility that it leads to unconducive conditions. It could proceed negatively which leads to tension or conflict. Social capital will be preserved, its existence is apparent from the collective action of the community. Collective action is able to maintain social capital that has been built in the community and external parties of Delas Village.

\section{Conclusion}

The strategy of livelihoods diversification undertook by the Delas Village community requires resources or assets exist in the community. There are five resources utilized by the community, namely natural, human, physical, financial and social capital. The fifth Resource is a very substantial asset for livelihood activities in Delas Village. The livelihood assets available are helpful for the people in generate income in post-tin mining era. In addition, the community has opened up for opportunities of diversified livelihoods such as by opening freshwater fishponds and raising livestock. These occupations were taken as alternative businesses aside of the previously-established agriculture and plantation sectors. The implementation of alternative occupation displays community creativity to be more open to various changes through the livelihood strategies. The diversification can also influence the relationships built by the community through cooperation in realizing a prosperous life and shared goals.

The successful post-tin mining strategy cannot undermine the support of social capital elements within the social system. In this case, the role of social capital is used as a support for changes in 
livelihood activities as survival strategy of the community in post-tin mining era. The role of social capital in the community does not necessarily happen instinctively. There are elements of social capital involved in its formation, such as high levels of community participation (social interaction), a system of community norms, mutual trust (trust), reciprocity, empathy, social solidarity and proactive attitudes. Building, bridging and social capital linking work synergistically with changes in livelihood activities in Delas Village community. Building is one of the strongest ties grows in community compared to bridging and linking. Bonding provides internal bonds that greatly influence community actions in forming further relations such as bridging and linking.

\section{References}

Baiquni M (2007) Strategi Penghidupan di Masa Krisis. Yogyakarta: Idial Media.

Belda F \& Christanto J (2012) Penelitian tentang Strategi Penghidupan Nelayan dalam Peningkatan Ekonomi Masyarakat di Kecamatan Sasak Ranah Pasisie dan Sungai Beremas.

Chapman R \& Tripp R (2006) Background Paper on Rural Livelihood Diversity and Agriculture. http://www.rimisp.cl/agren04/docs/BacgroundPaper3.doc.

Creswell WJ (2007) Research Design: Pendekatan Kualitatif, Kuantitatif dan Mixed. Pustaka Pelajar. Yogyakarta.

Dharmawan AH (2007) Pendekatan-Pendekatan Pembangunan Pedesaan dan Pertanian: Klasik dan Kontemporer. Makalah dalam "Apresiasi Perencanaan Pembangunan Pertanian Daerah bagi Tenaga Pemandu Teknologi Mendukung Prima Tani” 19-25 November 2006.

Ellis F (2000) Rural livelihoods and diversity in Developing Countries. Oxford: Oxford University Press.

Herdiyanti H (2017) Identifikasi modal sosial masyarakat terhadap restorasi lahan pasca tambang: Studi masyarakat Desa Bukit Kijang, Kecamatan Namang, Kabupaten Bangka Tengah. Society 5 (1):13-21. https://doi.org/10.33019/society.v5i1.16.

Martopo A (2012) Tesis: Kajian Penghidupan Berkelanjutan (Sustainable Livelihood) Di Kawasan Dieng (Kasus Di Desa Buntu dan Tambi Kecamatan Kejajar Kabupaten Wonosobo).

Niehof A (2004) The significance of diversification for rural livelihood system. Food Policy 29. www.Elsevier.com/located/foodpol.

Rahman B \& Ibrahim (2009) Menyusun Proposal Penelitian. Pangkalpinang: UBB Press.

Ramli (2007) Durability of Ferrocement Floating Structures Containing Rice Husk Ashll. In: Proceedings of the Fourth International Conference on Structural Failure, Durability and Retrofitting, Singapore.

Syahra R (2003) Modal sosial: Konsep dan aplikasi. Jurnal Masyarakat dan Budaya 5 (1).

Scoones I (1998) Sustainable Rural Livelihoods a Framework for Analysis. IDS Working Paper 72. Institute of Development Studies.

Supriyadi WW (2007) Pergeseran Mata Pencaharian Masyarakat Desa. FISIP: UNS.

Woolcock M \& Narayan D (2006) Social Capital: Implication for Development Theory, Research, and Policy Revisited. In: A Bebbington, M Woolcock, EG Scott, \& Olson EA. The Search for Empowerment: Social Capital as Idea and Practice at the World Bank. Kumarian Press, Inc. USA.

Woolcock M (2001) Using Social Capital: Getting the Social Relations Right in the Theory and Practice of Economic Development Princeton, NJ: Princeton University Press (forthcoming).

Woolcock M (2004) Using Social Capital: Theory and Practice of Economic Development Princeton, NJ: Princeton University Press (forthcoming).

Woolcock M \& Narayan D (2000) Social capital: Implication for development theory, research, and policy. World Bank Research Observer 15 (2):225-49. In: E Ostrom \& TK Ahn. Foundation of Social Capital.Massachusetts: Edward Elgar Publishing Limited. 